\title{
The Change of Financial Environment and
}

\section{the Evolvement of Financial Goals}

\author{
Jianhui Jian \\ North China Electric Power University, Beijing 102206, China \\ Zhongnan University of Economics \& Law, Wuhan 430060, China \\ E-mail: jianjianhui4894@sina.com
}

\begin{abstract}
With the changing financial environment, financial goals are constantly changing. In the course of development of financial theory, there were numerous financial goals theories, which are mainly "profit maximization, shareholders' wealth maximization, and stakeholders' wealth maximization." These financial goals basically reflect the business requirements of the market environment, the adaptation to the changing financial environment, and also reflect the different preferences of the different periods of property rights.
\end{abstract}

Keywords: Financial goals, Profit maximum, Interests of shareholders

\section{Introduction}

The financial goal of enterprise is the aim that the enterprise should achieve in the capital movement and the process of dealing with the economic stakeholder relationship. For the financial environment, the main composing factors of the corporate financial environment include the political factor, economic factor, legal factor and science-technology education factor. For all enterprises, their exterior financial environments are different. As viewed from the enterprise financing, the economic factor is the most influencing factor, which directly or indirectly influence the financial management of the enterprise, and provide a perfect exterior market for the enterprise, i.e. the capital market. The management of the enterprise is influenced and restricted by the financial environment, and the financial goal of the enterprise will change with the change of the financial environment.

Because of the core status in the financial researches, the financial goal can connect with the theory and practice. And the bridge functions of the enterprise interior management and exterior management are largely concerned in the history of financial researches, and the researches about the financial management goal developed from simple goal to complex goal, from single goal to multiple goals, from emphasizing short-term profits of the enterprise to emphasizing long-term sustainable harmonious development, from emphasizing the owners' benefits to emphasizing the development with multiple benefits such as the enterprise, the society and various stakeholders. For the dispute of financial goal, there is not a uniform opinion, and many factors such as the cultural background, political and legal environment, the productivity level and the interior governance structure of the enterprise will induce the change of the financial goal of the enterprise, which is not only from the limitation of the financial goal in the original cognition process, but also from the change of property relations (Yang Ruilong, Nie Huihua, 2006). In the development process of financial theory, there were numerous theories about the financial goal, and these opinions mainly included "the profit maximization, the shareholder fortune maximization and the stakeholder fortune maximization". These financial goals basically reflect the requirements of the enterprise to the market environment, and for the adaptivity of the finical environment change, these financial goals also embody the different preferences or property interests in different terms.

The evolvement course of the financial goal of enterprise is not single, and it is complex and changeable. There is not one sort of financial goal in one term, but there are different interests to be intermixed. But of course, in one term, there will be one sort of current tendency, and with the development of the time and the social economy, the variance of financial environment, the interest direction of the financial goal will be on speaking terms, and both of them will influence and drive each other.

\section{The financial goal of the profit maximization}

The financial goal of the enterprise first occurred before the First World War, and according to Adam Smith, David Richard and Marshall's economic theories, the financial goal of the profit maximization was the traditional point of view in western economic academy, and the point of view thought that the enterprise was the economic organization which took the payoff as the aim, and the profit creation was the necessary condition for the survival and development 
of the enterprise.

The financial goal of maximum profit is scientific, because the profit presents the contribution of the enterprise, but this goal doesn't reflect the time to acquire the anticipated profit, the proportion between the profit and the investment capital, and it doesn't consider necessary risk factor, which will induce short-term enterprise behaviors. With the process of time and the continual development of the market, after the Second World War, the west financial theory gradually turned to pay attention to the reasonable distribution of enterprise capitals and the function under the condition of the effective capital market, and the distribution of resources among various sorts of assets. And the measurement of the profit was turned into the maximization of the present value, and the net present value of the various investment projects of one enterprise was most, the net profit of the enterprise would be most. Because the goal of net present value maximization considers the time value of the coin, it will better than the goal of profit maximization, and it still doesn't consider the risk factor and the deficiency of the investment capital. The above opinion about the present value maximization is another thinking mode of the enterprise profit, and there is not essential change. But it is obviously limited to take the profit maximization as the financial goal. First, to take the profit gross as the financial goal ignores the relation between the investment and the output. As the final management result of the enterprise, the profit is the net output in the process of production and management, and if it is not compared with the capital investment, we can not judge the investment benefits. Second, the financial goal of profit maximization doesn't consider the relation between income and risk. Generally speaking, the income is positively proportional with the risk. It is not reliable for the financial goal without risk consciousness, which will induce that the enterprise pursues unilaterally the maximum profit without considering the size of the risk. More importantly, it will easily ignore the social responsibility and induce the short-term enterprise behaviors. The profit maximization may make the enterprise scarify the social resources to exchange the payoff and induce the short-term enterprise behaviors (Zhang Maoyan, 2005).

\section{The financial goal of shareholder benefit first}

The Second Industrial Revolution in the later of the 19th century not only largely drove the course of human civilization, but also brought very important opportunity for the development of the corporate system. With the separation between the property and the management right, the profit maximization has not been the reasonable noun to describe the goal of the enterprise, and human eyes have gradually turned to the shareholders' benefits.

Through many forms such as stock and bond, the extension of the enterprise scale and the increase of the shareholder number make the ownership structure highly decentralized, and as the owner of the enterprise, the shareholders are gradually far from the management of the enterprise. Berle and Means found that the property and the control right begun to separate in these companies, and modern companies had been controlled from the "owners" to the "managers". Under this background, it is very necessary to emphasize the shareholders' benefits and realize the supervision to the managers, and the view of "shareholder benefit first" was formed in this term. Therefore, with the increasing perfection and maturation of the shareholder system, the respect of the financial goal is turned from the profit of the enterprise to the benefit of the shareholder, and the basic opinion of the shareholder value tropism is that the company is owned by the shareholders and the director is the assignee of the shareholder, and its first task and main responsibility are to create values for shareholders and ensure the benefit of the shareholder is the final respect of the company (Li Huaian, 2005). In 1930s, the emphasis of the US public policy is to protect the benefit of the shareholders. The "Stock Act" of 1993 and the "Securities Act" of 1934 were to take the protection of shareholder benefit as the final aim. In the first 30 years of the 20th century, the "shareholder benefit first" had been the standard cognized by the company theory, the legal system and the public policy together.

With the development of time, in the theory of "shareholder benefit first", the financial goal gradually develops to the stock price maximization which became into the financial goal recognized by western enterprises. The market value considers not only the risk character of the company, but also the present and potential EPS, bonus quantity and the anticipation of time. But the deficiency of the stock price maximization is that the stock price is the objective evaluation for the participators in the enterprise exterior capital market, and it is their opinions about the enterprise managers represent stockholders to finance and exert the operations, and it possesses large uncertainty especially under the premise of the imperfect capital market. In 1980s, many companies proposed the financial goal to make the shareholders' fortune maximum. It not only includes the maximization of the stock price, but also reflects the exterior objective evaluation of the enterprise, eliminates all risks and uncertain factors, which can promote the reasonable flow of the social resource. But the opinion still takes the shareholder as the core, and it can not fairly consider the objective need of other property bodies.

So far, the stockholder benefit oriented corporate value concept is still the mainstream concept for the economics, management science and corporate law, but in recent years, the critical opinions from various aspects are more and more. The main critical opinions include following aspects. First, many people thought that the concept of the stockholder value tropism was not responsible as viewed from the sociology and the economics, and it also doesn't accord with the principle of commercial morality, but it ignores the importance of the stakeholders, and these 
stakeholders include enterprise employees, clients, the community and the environment of the company, and even shareholders' long-term interests. Even in the extremely free market economy such as US market, many people thought it was too narrow and marble to simply pursue shareholder values (Jensen, 2001). Second, the corporate value view of shareholder orientation excludes other stakeholders' benefits except for the shareholders from the goal of the company, which not only runs in the opposite direction with the theory about strengthening the social responsibility of the company, but its theory can not justify itself (Liu Junhai, 1999). Finally, the corporate value view of the shareholder orientation has not adapted with the developments of the society and the economy, and the variance of the corporate management environment. The basic premise confirmed by the shareholder value orientation includes that the main responsibility of the directors is responsible for the shareholders, and the shareholders are the absolute managers for the corporate responsibility and control right. This opinion was first generated in the early capitalism society, and at that time, the individuals as the investors and the companies as the invested objects had direct relations, and human possessed the real senses as the shareholders of the company. But at present, the situation is different, the company influences the group which is bigger than the range of the shareholder, and it is also influenced by the group, and every core of the company is the relation net of stakeholders, and the every relation net is established on the mutual dependences.

\section{Fortune maximization for stakeholders}

The economic crisis from 1929 to 1933 was another turning point in the US and world economic history. The Great Depression brought serious social costs, and people begun to reevaluate the value of the company and the opinion of the shareholder benefit maximization. But with the continual extension of the company scale and the capital, a series of social conflicts such as polarization between the rich and the poor, the social impoverishment, the labor problem and the labor and capital conflict are generated. Some scholars begin to discuss the social responsibility of the company on the moral layer aiming at a serious of problem in the management of the company. So the concept of the stakeholder enters into the historical stage.

Aiming at the Berle's opinion about the shareholder benefit first, Dodd put forward that the social responsibility of the company was the base of the citizen status in 1995 . He thought that since the company is regarded as the independence "juridical person", it should assume citizen's responsibility, i.e. the corporate management layer should not only assume the "fiduciary responsibilities" for shareholders, but perform the citizen responsibility of the company as the assignee of the "company electorates", though that might induce the decrease of the shareholder value. In 1960s to 1970s, the concern to the stakeholders in the management had been a sort of popular opinion, and the consumer dominion movement, the environment protection and other social movements had produced large influences, and the company begun to care about the employees, the community and the public business, and the concept of "social responsibility" had been carried out. For the legislation system, US begun leaning to stakeholders from shareholders, and issued many acts to protect stakeholders. In this term, the concern and protection about stakeholders could largely relax the social conflicts intensified by the Great Depression and the Second World War, and it was also the necessary result of the evolvement of the corporate management concept. The protection for the employees, the consumers and the natural environment embodied the social advancement, and it was a sort of reasonable modification to simply emphasize shareholders' benefits, and it further influenced the opinion of the social responsibility of the company.

The stakeholder means various personnel and organizations in the management of the company which can become into the undertakers of the risks and the sharers of the benefits. This shows that the shareholders, the creditors, the employees, the suppliers, the consumers, the communities, relative groups, social organizations and the government all can be regarded as the stakeholders of the company, and obviously, the range of the stakeholder is broad. US scholar Clarkson thought that "stakeholders are natural persons or social groups which take or claim the property, the right or the benefits in the past, present or future activities of the company", and Clarkson further classified the stakeholders of the company into two sorts, i.e. the primary stakeholder and the secondary stakeholder. The primary stakeholder means the indispensable persons for the survival of the company, and it includes the owners, the clients, the employees, the communities, the government, and even the suppliers and the creditors. The secondary stakeholder includes other organizations and individuals which have little relations with the survival of the company, but the management of the company will influence their benefits. The secondary stakeholders include relative environment activists, media, scholars, critics, trade organizations, and even competitors. The so-called "stakeholders" means "the property subjects which can create fortunes for the enterprise through special assets investment". The governance of "stakeholder" makes all property subjects which have created fortunes for the company through the investments of the special assets to participate in the organizational mechanism, the decision control mechanism and the benefit distribution mechanism for the company. US economist Coase put forward the "enterprise contract theory", and defined the enterprise as "the business of the production agents, i.e. the long-term authorized contract relation between the labor and the capitals", so more scholars begun to understand the company as the combination of a series of contracts among the material capital owners, the human capital owners, creditors and other stakeholders, i.e. the individuals and organizations with different capitals could distribute their own responsibilities, rights and benefits through the negotiation, and the result of the 
negotiation was the promissory enterprise contract. So the company is not the benefit subject belonging to one shareholder, and the creditors and shareholders invest material capitals. The managers and employees are the investors of the human capitals, and the consumers and communities invest social capitals (reputation assets). As the contractor, the enterprise participators all possess the benefit claim rights for the enterprise factors invested by them, and this sort of benefit can be presented by the economic form or the non-economic form (Li Xinhe, 2004).

Under modern market economic conditions, the goal of the enterprise is not only to pursue the benefit maximization of the capital for owners, and the enterprise is the sum of multilateral contract relations, or the "contract network" composed by the human capital and material capital, and the equality and the independence of the contract contained in the benefit subjects require that the subjects of the corporate management structure should be equal and independent. These subjects associated each other include shareholders, creditors, managers, producers, consumers, suppliers and other relative benefit subjects, which compose the stakeholders, but the efficiency of the enterprise should be established on the equality of stakeholders. Under this new corporate governance logic, the enterprise should emphasize not only shareholders' benefits, but also other stakeholders' actual participations. Concretely speaking, there should be stakeholder representatives except for the shareholders in the directorate and the board of supervisors (such as the employee representative, the creditor representative) to exert the function of stakeholders. The shareholders' benefit should not be regarded as the most important thing, and it should be one party in the stakeholder network. The company is a benefit relation network, and various factors in every relation network should base on interaction, and the managers of the company in the company governance should not only try to realize shareholders' benefits, but also consider other stakeholders' benefits. After 1980s, many countries begun to regulate that the manager take charge for stakeholders except for shareholders in the company law, i.e. they wanted to establish a sort of corporate governance mode about "stakeholders".

\section{References}

Dodd. (1995). A Stakeholder Framework for Analyzing and evaluating Corporate Social Performance. Academy of Management Review.

Li, Huaian. (2005). Corporate Social Responsibility: From Concept to Practice. Nankai Management Review (in Chinese), 10: 73-74.

Li, Xinhe. (2004). The Choices of Company Values and its Evolution Trend. Accounting Research (in Chinese), 10:132-142.

Liu, Junhai. (2002). Corporate Social Responsibility. Law Press, pp. 30-31.

Michael C. Jensen. (2001). Value Maximization, Stakeholder Theory, and the Corporate Objective Function. The Monitor Group and Harvard Business School, 10.

Yang, Ruilong \& Nei, Huihua. (2006). Incomplete Contract Theory: A Summary. Economic Research (in Chinese), 2: 55-59.

Zhang, Maoyan. (2005). The Choice of the Best Financial Targets from the Evolution of Corporate Financial Goals. Business Management, 10:103-107. 